\title{
Commentary: Tip of the iceberg
}

\author{
Marian R. Hohenwarter, BA, ${ }^{\mathrm{a}}$ and Chadrick E. Denlinger, $\mathrm{MD}^{\mathrm{b}}$
}

\author{
From the ${ }^{\mathrm{a} M e d i c a l}$ University of South Carolina, Charleston, SC; and ${ }^{\mathrm{b}}$ Division of Cardiothoracic Surgery, Med- \\ ical University of South Carolina, Charleston, SC. \\ Disclosures: Authors have nothing to disclose with regard to commercial support. \\ Received for publication Dec 2, 2018; accepted for publication Dec 3, 2018; available ahead of print Jan 9, 2019 \\ Address for reprints: Chadrick E. Denlinger, MD, Department of Surgery, Division of Cardiothoracic Surgery, \\ Medical University of South Carolina, 114 Doughty St, Charleston, SC 29425 (E-mail: denlinge@ musc.edu). \\ J Thorac Cardiovasc Surg 2019;157:2093 \\ $0022-5223 / \$ 36.00$ \\ Copyright (C) 2018 by The American Association for Thoracic Surgery \\ https://doi.org/10.1016/j.jtcvs.2018.12.007
}

Following an esophagectomy, patients may follow an uncomplicated pathway to recovery or they may divert from this intended pathway because one of several different complications. One of the most concerning complications is a gastroesophageal anastomotic leak, which has an incidence of $10 \%{ }^{1}$ This complication leads to several downstream effects, including a protracted hospitalization, frequent need for rehabilitation, and increase risk for mortality. Although one can calculate hospital costs to determine the impact of this complication on the patient and the health care system, this only represents the tip of the iceberg.

Patients with high-grade anastomotic leaks have a far greater risk for needing subsequent operations as well as a prolonged stay in the intensive care unit. Each factor directly increases hospital costs and the risk for additional iatrogenic complications, which further escalate the hospital cost and length of stay. According to Agzarian and colleagues ${ }^{2}$ in this issue of the Journal, the median time required to treat this complication is 73 days, with an associated additional cost of $\$ 119,822$, demonstrating that average treatment costs are 2.6 times greater than those without a leak. The largest contributors to cost for all patients are intensive care stay $(30 \%)$, hospital room $(17 \%)$, pharmacy $(16 \%)$, and surgical intervention $(13 \%)$. As a result of the prolonged recovery period, patients also are more likely to be discharged to a rehabilitation facility instead of their own home. ${ }^{3}$ In a bundled payment model, these added costs, which are substantial, will be incurred by the institution in which initial treatment was performed.

An additional cost to consider is the emotional toll on patients and their families. Studies have confirmed a greater risk of depression among patients with postoperative complications and this relates to a diminished functional capacity and greater dependence on others. ${ }^{4}$ Even after the patient eventually returns home, they will likely have a prolonged dependence on other family members, who are taking additional time off of work, for personal care as well as assistance with necessary tasks of living that

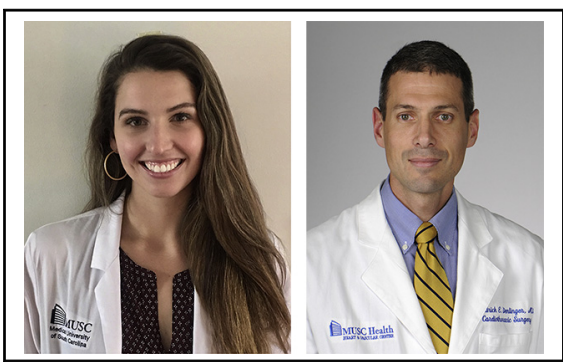

Marian R. Hohenwarter, BA, and Chadrick E. Denlinger, MD

\section{Central Message}

The costs of anastomotic leaks extend well beyond the initial hospitalization. Other costs include rehabilitation, antibiotics, radiologic studies, and delayed return to work for patient and family.

See Article page 2086.

the patient is not able to manage. At this point, the actual cost of the anastomotic leak extends well beyond the initial hospitalization because of the impact this event has on the patient's entire family. All of this additional cost is stacked up against a diminished life expectancy for the patient who may likely never bounce back to the level of vitality that they had when they walked into the hospital for their elective operation. ${ }^{5}$ Determining the increased cost of hospitalization resulting from an anastomotic leak is important, and realizing the far greater cost to the patient and their family further emphasizes the importance of determining means to reduce the incidence of this devastating complication.

\section{References}

1. Kassis ES, Kosinski AS, Ross P Jr, Koppes KE, Donahue JM, Daniel VC Predictors of anastomotic leak after esophagectomy: an analysis of The Society of Thoracic Surgeons General Thoracic Database. Ann Thorac Surg. 2013;96: 1919-26.

2. Agzarian J, Visscher SL, Knight AW, Allen MS, Cassivi SD, Nichols FC III, et al The cost burden of clinically significant esophageal anastomotic leaks-a steep price to pay. J Thorac Cardiovasc Surg. 2019;157:2086-92.

3. van der Sluis PC, van der Horst S, May AM, Schippers C, Brosens LAA, Joore HCA, et al. Robot-assisted minimally invasive thoracolaparoscopic esophagectomy versus open transthoracic esophagectomy for resectable esophageal cancer: a randomized controlled trial. Ann Surg. October 10, 2018 [Epub ahead of print].

4. Hellstadius Y, Lagergren J, Zylstra J, Gossage J, Davies A, Hultman CM, et al A longitudinal assessment of psychological distress after oesophageal cancer surgery. Acta Oncol. 2017;56:746-52.

5. Luc G, Durand M, Chiche L, Collet D. Major post-operative complications predict long-term survival after esophagectomy in patients with adenocarcinoma of the esophagus. World J Surg. 2015;39:216-22. 